\title{
Equine milk and its potential use in the human diet
}

\author{
Ícaro Marcell Lopes Gomes BARRETO ${ }^{1}$, Adriano Henrique do Nascimento RANGEL ${ }^{1}$, Stela Antas URBANO ${ }^{1 *}$, \\ Joadilza da Silva BEZERRA ${ }^{1}$, Chiara Albano de Araújo OLIVEIRA ${ }^{2}$
}

\begin{abstract}
Our objective was to address the use of equine milk for human consumption, highlighting important compositional aspects and peculiar characteristics of this milk. Equine milk stands out for its similarity to breastmilk in compositional aspects considering the quality of the protein and lipid fractions, and due to the presence of important bioactive compounds. The high percentage of whey proteins and the structure of the protein micelles favor equine milk's digestibility, while its bioactive protein richness and the good relationships established between fatty acids highlight it as a functional food. Children who are allergic to cow's milk protein, the elderly and/or people affected by skin and gastrointestinal disorders are potential consumer of equine milk. Assays have proven the therapeutic properties of koumiss; high tolerability of equine milk by children who are intolerant to cow's milk; beneficial effects in treating atopic dermatitis and chronic diseases of the gastrointestinal tract; and potential of this milk in the prophylaxis and/or nutritional support of patients affected by several diseases. Scientific findings highlight the potential of equine milk as a beneficial food for human health, regarding both its nutritional aspects and functionalities, which could contribute to the increased demand for equine milk in global dairy market.
\end{abstract}

Keywords: functional food; bioactive compounds; kumis/koumiss; lysozyme.

Practical Application: Ponder the particularities of equine milk that allow it to be seen as a promoter of human quality of life.

\section{Introduction}

Milk represents an essential source of nutrients for mammals during the neonatal period (Potočnik et al., 2011). Specifically in the human species, milk is consumed during all stages of life due to its richness in nutrients. The history of milk as food for humankind lies between mythological and religious aspects. In Greek mythology, milk was regarded as a link between the divine and the profane, which is why Zeus offered milk to his son Hercules. It was also believed that the immortality power of the Gods was derived from consuming milk. For the Hindu people, milk had such a meaningful value that it was treated as an offering. In Roman mythology, the Romulus and Remus brothers were fed wolf's milk, and among the Hebrews, milk was regarded as a "blessed food", symbolizing life and fertility. Milk underlies the precepts of Buddhist doctrine, and it is also referenced in the Bible more than 50 times along with its derivatives. In fact, milk is considered the most natural functional biofluid (Nikkhah, 2012).

Historians portray that the domestication of bovine cattle happened around $8000 \mathrm{BC}$ with the purpose of providing meat and traction; however, studies by European scientists indicate that cows had begun to be milked in England and Western Europe in $6000 \mathrm{BC}$ for the purpose of feeding the population. According to Valverde (2015), the domestication of cattle boosted the Neolithic Revolution, and goats and sheep were also domesticated for their milk after cows. Specifically regarding equine milk, Aristotle (322 BC) reported the existence of a dairy product in Mongolia that processed mare's milk to transform it into a fermented product with an alcohol content of $3 \%$, and Herodotus also reported something very similar performed by the Scythians; both were referred to as airag, kumis/koumiss, kumisou or kymys, a traditional food of great importance in the diets Asian inhabitants, and which is still consumed to the present day (Malacarne et al., 2002).

Nowadays, a considerable number of equines have been farmed in several countries of the world for milk production (Danków et al., 2006), and according to Potočnik et al. (2011), about 30 million people consume equine milk, with an emphasis on the inhabitants of Western Europe and Central Asia (Csapó et al., 1995). Due to its nutritional and therapeutic properties, a growing interest has also been observed in recent years in Belgium, France, Germany and Italy, where equine milk has been studied as a milk substitute for newborns and pre-mature infants (Malacarne et al., 2002), in addition to its more frequent use as dietary supplement for elderly citizens, convalescent individuals, and mainly for children allergic to cow milk (Danków et al., 2006).

In relation to the world market where cow's milk is the most produced and most consumed ( $85 \%$ of all milk), mare's milk still accounts for less than $0.1 \%$ of all global production (Faye \& Konuspayeva, 2012). In Brazil, there are no publications reporting official data regarding the production of equine milk, nor on its

${ }^{1}$ Unidade Acadêmica Especializada em Ciências Agrárias, Universidade Federal do Rio Grande do Norte - UFRN, Macaíba, RN, Brasil

${ }^{2}$ Escola de Medicina Veterinária e Zootecnia, Universidade Federal da Bahia - UFBA, Salvador, BA, Brasil

*Corresponding author: stela_antas@yahoo.com.br 
consumption by Brazilians. However, it is important to point out that prospects for the market of equine's milk are positive given the scientific discoveries revealing that this milk is rich in bioactive compounds, as well as the nutritional quality of the lipid fraction. Furthermore, the compositional similarity between human breastmilk and equine milk favors its recommendation as food for human infants, which can be seen as a driving force for exploiting equine milk in Brazil and in the world.

The following review aims to address the use of equine milk for human consumption, punctuating important compositional aspects and peculiar characteristics of this milk that allow it to be seen as a promoter of human quality of life. Other applications of equine milk and colostrum will also be opportunely addressed throughout the manuscript, since several products derived from these raw materials have been referred to as being beneficial to human health.

\section{Characteristics of equine milk that make it suitable for human consumption}

Depending on the nature of animal ecology, evolution, genetics and nutritional management, the composition and nutritional properties of milk differ considerably among mammals (Nikkhah, 2012). Equine's milk is poor in energy ( 425 to $825 \mathrm{kcal} / \mathrm{kg}$ ), fat (1.0 to $1.5 \%$ ) and crude protein (1.89 to $2.87 \%$ ), but rich in lactose (6.5 to $6.6 \%$ ) (Pagan \& Hintz, 1986). It has a different composition compared to other domestic species, however, it maintains a considerable resemblance to breastmilk (Table 1). Human and equine milk are similar in terms of sugar supply (lactose and galactose), proteins and minerals, but they differ in fat content, which is markedly higher in human breastmilk (Malacarne et al., 2002). Therefore, based on the crude composition, equine milk appears as the most adequate food for human infants when compared to bovine milk (Marconi \& Panfili, 1998).

The composition of equine's milk can be influenced by several factors: age, calving order, live weight of the mares, diet, environmental conditions and lactation stage, with the latter being the most important. The concentration of the various constituents of milk decreases from the beginning of the lactation period, with the exception of lactose, which increases in the beginning and decreases at the end of lactation (Santos et al., 2005). The presence of pathologies, among which we can highlight mastitis, constitutes another important difference in milk composition (Reis et al., 2007). Also according to Costa (2013), breed and genetics may influence milk composition, especially for protein, fat and lactose concentration. However, it is very unlikely that the performance - joint or isolated - of these variation sources would be effective in dramatically altering the essence of equine milk composition, which tends to remain within the mean values presented in Tables 1 and 2 .

The composition of equine milk offers some peculiarities in its use. Its non-suitability for manufacturing derivatives such as cheeses and butter due to its low casein and fat contents is a typical example, and suggests that its preferable use in human food is as a liquid. However, even this form of use has a peculiarity: the equine milk is not very stable above $40^{\circ} \mathrm{C}$, requiring it to be cooled immediately after the milking and consumed no longer than nine hours after milking (Danków et al., 2006). Thus according to Marconi \& Panfili (1998), equine milk is

Table 1. Composition and percentage of casein and whey proteins among different mammal species.

\begin{tabular}{|c|c|c|c|c|c|c|}
\hline Component & Mares & Donkeys & Cows & Sheep & Goats & Humans \\
\hline Fat (g/kg) & 12.0 & $3-18$ & 36.1 & 75 & 41 & 36.4 \\
\hline Protein (g/kg) & 21.4 & $14-20$ & 32.5 & 54.5 & 34 & 14.2 \\
\hline Lactose (g/kg) & 63.7 & $58-74$ & 48.8 & 49 & 47 & 67.0 \\
\hline Ash (g/kg) & 4.2 & $3-5$ & 7.6 & 8.5 & 7.7 & 2.2 \\
\hline Crude energy (kcal/kg) & 480 & $384-490$ & 674 & - & 670 & 677 \\
\hline \multicolumn{7}{|l|}{ Protein fraction (\%) } \\
\hline Casein & 50.0 & - & 77.3 & 77.5 & 70.6 & 26.0 \\
\hline Whey proteins & 38.8 & - & 17.5 & 20.0 & 21.7 & 53.5 \\
\hline
\end{tabular}

Source: Adapted from Potočnik et al. (2011) and Claeys et al. (2014).

Table 2. Mineral composition of milk from different mammal species.

\begin{tabular}{ccccccc}
\hline Minerals $(\mathrm{mg} / 100 \mathrm{ml})$ & Mares & Donkeys & Cows & Sheep & Goats & Humans \\
\hline Calcium & $50-135$ & $33-115$ & $112-123$ & $159-242$ & $85-198$ & $28-34$ \\
Phosphorus & $20-121$ & $32-73$ & $59-119$ & $124-175$ & $79-153$ & $14-43$ \\
Potassium & $25-87$ & $24-75$ & $106-163$ & $94-162$ & $140-242$ & $16-36$ \\
Magnesium & $3-12$ & $2-8$ & $7-12$ & $53-62$ & $3-4$ \\
Sodium & $8-58$ & $10-27$ & 58 & $30-75$ & $28-59$ & $10-18$ \\
Chlorine & 19 & $14-50$ & $100-119$ & $99-160$ & $104-209$ & $60-63$ \\
Iron & $0.02-0.15$ & $0.04-0.26$ & $0.03-0.10$ & $0.08-0.10$ & $0.05-0.10$ & $0.04-0.20$ \\
Zinc & $0.09-0.64$ & $0.10-0.30$ & $0.30-0.55$ & $0.40-0.90$ & $0.40-0.60$ & $0.20-0.40$ \\
Copper & $0.02-0.11$ & $0.01-0.03$ & $0.01-0.08$ & $0.03-0.05$ & $0.02-0.05$ & $0.02-0.06$ \\
\hline
\end{tabular}

Source: Adapted from Claeys et al. (2014). 
highly sensitive to preservation and transformation processes due to these compositional particularities.

Still regarding these particularities, they are even more striking when considering single structural components, with special attention to the protein and lipid fractions of equine milk (Malacarne et al., 2002). The protein profile of this milk corresponds to the desired amount in human diets due to its whey protein:casein ratio and the spongiform structure of the micelles, which make this milk more physiologically digestible than cow milk (Egito et al., 2001). The equine milk protein fraction shows that approximately $40 \%$ of the total proteins are whey proteins, which corresponds to more than twice the value observed in cow milk (Malacarne et al., 2002), thereby largely contributing to the greater digestibility of equine milk considering that whey proteins are considerably less demanding to the secretion of hydrochloric acid when compared to caseins during the digestion process (Oliveira \& Osório, 2005). For this reason, equine milk has stood out in treating children who have cow milk protein allergy (CMPA), especially during early childhood. This condition affects 2 to $5 \%$ of the children under three years of age (Rangel et al., 2016).

It is also noted that milk whey proteins are composed of high lysozyme and lactoferrin percentages (Table 3), bioactive proteins which exhibit antibacterial, antifungal, anti-inflammatory and anticancer properties, in addition to providing a greater supply of essential amino acids to men (Markiewicz-Kęszycka et al., 2013). According to Danków et al. (2006), mare’s milk has twice as much lysozyme content as human breastmilk, which explains its beneficial effects on canker sores, upper airways diseases, as well as in healing wounds and postoperative scars. According to Pikul \& Wójtowski (2008), mare's colostrum and milk have been increasingly used as natural pharmacological agents to assist in treating various gastrointestinal tract disorders due to these characteristics, including chronic inflammation of the intestinal wall, neurodermatitis and psoriasis.

Other protein fractions of equine milk that are beneficial to human health are immunoglobulins and growth factors. Equine milk has high immunoglobulin content when compared to human and ruminant milk (Table 2), with IgG present in higher amounts in colostrum and IgA largely present in mature milk. Concerning growth factors, IGF-1 has been positively correlated with reducing the risk of breast, prostate and colon cancers, and stands out in equine milk. However, it is pertinent to clarify that studies are not yet conclusive regarding the beneficial effect of exogenous sources of growth factors on human health (Claeys et al., 2014).

The fat content of equine milk is markedly lower than those in human and ruminant milks, which is reflected by its caloric value. However, this fat consists of $80-85 \%$ triglycerides, $9.5 \%$ free fatty acids and 5-10\% phospholipids, while human and bovine milk have $97-98 \%$ of their fat composed by triglycerides. In addition, equine milk fat globules measure approximately 2-3 $\mu \mathrm{m}$, presenting an even smaller mean diameter than those of human breastmilk ( $4 \mu \mathrm{m}$ ), implying in the efficiency of lipid metabolism which tends to be greater when fat globules are smaller (Malacarne et al., 2002; Claeys et al., 2014).
The nutritional quality of the equine milk lipid fraction which is composed of small amounts of stearic and palmitic acids and high amounts of linoleic and linolenic acids (Salamón et al., 2009), supports the recommendation of providing equine milk to humans. These latter fatty acids are precursors of eicosapentaenoic acid (EPA) and decosahexaenoic acid (DHA), which are involved in the prevention of cardiovascular diseases and hypertension by inhibiting the synthesis of triglycerides at a hepatic level (Gibson \& Makrides, 2000). In addition to the representativeness of absolute numbers, it is worth noting that equine milk and colostrum also present good values of established ratios between fatty acids (Table 4), which according to Arruda et al. (2012), are important for assessing and identifying the food risk factor in relation to plasma cholesterol levels in humans.

\section{Equine milk as food for humans}

\subsection{Fermented milk}

The use of mare's milk for human consumption inevitably began in the secular tradition of peoples from Central Asia, Mongolia, and the former Soviet Union in producing/manufacturing kumis/koumiss, a lactic-alcoholic beverage produced from equine milk with outstanding nutritional importance for the aforementioned populations (Ørskov, 1995). The production of kumis/koumiss, which is now carried out on an industrial scale, was handcrafted from the inoculation of fresh and raw mare's

Table 3. Mean percentages of protein fractions from the whey of mare, human and cow milk.

\begin{tabular}{cccc}
\hline Component (\%) & Mare & Human & Cow \\
\hline a-lactalbumin & 28.5 & 42.3 & 53.5 \\
B-lactalbumin & 30.7 & - & 20.1 \\
Immunoglobulins & 19.7 & 18.1 & 11.7 \\
Serum albumin & 4.45 & 7.56 & 6.20 \\
Lactoferrin & 9.89 & 30.2 & 8.38 \\
Lysozyme & 6.59 & 1.66 & Traces \\
\hline Source: Adapted from Piesza et al. (2016). & &
\end{tabular}

Table 4. Cholesterol concentration (mg. $\mathrm{L}^{-1}$ ) and ratios between fatty acids in equine, human and bovine milk.

\begin{tabular}{cccc}
\hline Relationship & Equine milk & Human milk & Cows milk \\
\hline C18:0 & 2.09 & $5.63-6.45$ & 10.51 \\
C18:1 cis9 & 25.04 & $31.26-37.45$ & 20.5 \\
C18:2n-6 LA & 3.81 & $15.24-17.73$ & 3.13 \\
C18:3n-3 ALA & 17.51 & $0.6-1.36$ & 0.59 \\
SFA & 49.35 & $38.52-44.3$ & $53.67-63.52$ \\
MUFA & 33.59 & $36.56-42.92$ & $30.12-38.19$ \\
PUFA & 21.33 & $18.24-19.1$ & $3.63-5.84$ \\
PUFA:SFA & 0.39 & 0.47 & $0.06-0.1$ \\
Atherogenicity index & 0.85 & 0.74 & $1.63-2.3$ \\
Thrombogenicity index & 0.38 & $0.68-1.0$ & $2.12-2.83$ \\
Cholesterol & 2.04 & $100-200$ & $155-195$ \\
\hline
\end{tabular}

LA: linoleic acid; ALA: $\alpha$-linolenic acid; PUFA: polyunsaturated fatty acids; MUFA: mono-unsaturated fatty acids; SFA: saturated fatty acids. Source: adapted from Pieszka et al. (2016). 
milk with part of the remaining liquid from the previous day (Cagno et al., 2004). Mainly by the action of Lactobacillus delbrueckii subsp. bulgaricus, Lactobacillus casei, Lactococcus lactis subsp. lactis, Kluyveromyces fragilis and Saccharomyces unisporus, lactic acid (7-18 g/kg), ethanol (6-25 g/ $/ \mathrm{kg})$ and carbon dioxide (5-9 g/kg) are obtained after 3-8 hours as the final products of the spontaneous fermentation of lactose (Litopoulou-Tzanetaki \& Tzanetakis 2000).

Kumis/Koumiss can be more ( $\mathrm{pH} 3.3-3.6)$ or less ( $\mathrm{pH}$ 4.5-5.0) acidic and have the lactose converted into more $(90 \%)$ or less (50\%) lactic acid, according to Danova et al. (2005), who also stated that "moderate" kumis has better taste and fragrance when compared to "strong" or "light" kumis. The same authors point out that the composition directly depends on the milk composition of each mare, but on average it has $1.12 \%$ protein, $2.05 \%$ fat, $2.20 \%$ lactose, $1.15 \%$ lactic acid, 1.65\% alcohol and $91.8 \%$ water and salts.

Due to the protective capacity conferred by probiotics against pathogens from the intestinal lumen, fermented dairy products stand out in the market as human health promoters because they are considered important suppliers of probiotics (Shi et al., 2012). Along with yogurt and kefir, Kumis is the most popular and efficient dairy product in providing viable Lactobacillus acidophilus and Bifidubacterium bifidum. These species are already known for their importance in reestablishing the balance of the intestinal microflora. In addition to probiotics, other important bioactive compounds such as peptides, organic acids and microorganism metabolites (with antibiotic function) are present in kumis, thus characterizing it as a functional food (Lv \& Wang 2009).

Regarding the therapeutic properties of kumis, Chen et al. (2010) indicated that it is rich in angiotensin-I-converting enzyme (ACE) inhibitor peptides, peptides with antihypertensive effects and which have also been suggested as beneficial to cardiovascular health. Furthermore, Zhang \& Zhang (2012) reported that the beverage can stimulate the immune system and promote antibacterial activity, in addition to presenting a hypocholesterolemic effect. However, the authors emphasized that the major medicinal contribution of the fermented product is related to treating chronic diseases, with proven effects in the treatment of patients with tuberculosis.

\subsection{Raw, frozen or powdered milk}

Although kumis is the most traditional and the most common form of equine milk consumption by Asian people, we know that this is not the only way of incorporating this milk into the human diet. Raw, frozen, freeze-dried or as powder in capsules are other possibilities highlighted by Pieszka et al. (2016) for consuming Equine milk. The lack of palatability, protein-related allergies, unfavorable immune responses, hyperlipidemia and intestinal intolerances continue to limit the preference of cow milk to certain groups of people (Carroccio et al., 2000), which has directed the focus of researchers to investigate the nutritional capacity of milk from lesser known species (Tafaro et al., 2007). Within this context, mare's milk not only stands out for its nutritional quality (as already mentioned in this review), but also for its attractive flavor and appearance, which has favored ingestion by young consumers (Salimei \& Fantuz, 2012). According to Businco et al. (2000), the pleasant flavor resulting from the high lactose content make equine milk much more acceptable than the protein hydrolysates and/or soy milks that are often recommended for allergic patients.

The importance of milk in children's nutritional plan is no longer questionable, however the moderate frequency of allergies to cow milk protein, as already highlighted by Rangel et al. (2016), instigates the development of studies which may provide alternatives to the problem. In this sense, Businco et al. (2000) conducted the pioneering study (in vivo and in vitro) to test the allergenicity of mares' milk in a population of 25 children ranging in age from 19 to 72 months with severe allergy to cow milk protein. The results indicated that $96 \%$ of the children were tolerant to mare's milk. According to the authors, the amino acid sequences of some milk proteins differ from those of cow milk, mainly a-lactalbumin, which may be a key factor in the low allergenicity of mare's milk. Carroccio et al. (2000) also recommended mare's milk as a substitute for cow milk in allergic children. However, despite the seemingly encouraging results, Vita et al. (2007) stated that they are not conclusive, and it is always necessary to test a child's tolerability in relation to mare's milk.

Lara-Villoslada et al. (2005) found that the balance between casein and whey proteins determines the allergenicity of cow milk. In fact, the amount of whey proteins is much higher in equine milk (Malacarne et al., 2002; Pecka et al., 2012), which translates into health promotion for consumers diagnosed with allergic problems.

In relation to the elderly, Salimei \& Fantuz (2012) point out that nutrition is crucial for the immune response of these consumers, and that equine milk can be an interesting food/alternative for this group. An important aspect that may partly explain children's tolerability to mare's milk and their indication to implement it into elderly diets is the low casein:total protein ratio when compared to cow, buffalo or sheep's milk, and the low soluble calcium content, which guarantees the formation of a soft clot in the stomach, thereby favoring the digestive process of the milk (El-Agamy, 2007).

Other beneficial effects of equine milk consumption were seen in patients with atopic dermatitis, an immune reaction in the body that produces excessive amounts of IgE and results in itchiness, redness and dry skin (Pieszka et al., 2016). A clinical trial was conducted by Foekel et al. (2009) with a group of 39 people diagnosed with atopic dermatitis, who received $250 \mathrm{ml}$ of unpasteurized mare's milk before their morning meal for a period of 16 weeks. Throughout the same period, one placebo group received a hypoallergenic infant formula enriched with lactose to confer a similar taste. The authors found significant relief of symptoms after the $12^{\text {th }}$ week of milk consumption and related the result to the influence that equine milk has on regulating the intestinal flora, which ends up affecting the immune system. They also highlighted that lactoferrin in combination with lysozyme may have inhibited the growth of pathogenic cultures, thus contributing to the positive outcome. 
Schubert et al. (2009) evaluated the efficiency of a daily $250 \mathrm{ml}$ intake of mare's milk by young patients with chronic diseases of the intestine (ulcerative colitis and Crohn's disease). The patients presented reductions in abdominal pains and the amount of blood present in the feces, which allowed for reducing the amount of administered medicines, suggesting that mare's milk can provide a better quality of life for those affected by such diseases.

Pieszka et al. (2016) pointed out that equine milk can be nutritionally used as a prophylactic and/or supportive measure in the treatment of some diseases, not being directly associated with the treatment of any specific disease. This would be in addition (of course) to the possibility of using it as a substitute for cow milk. In Kazakhstan, for example, a project has been conducted with the purpose of marketing a drug based on mare's milk which may be useful in relieving tuberculosis symptoms. On the other hand, Abdel-Salam et al. (2010) found that the administration of equine milk enriched with fiber and probiotics in rats was efficient in reducing the effects of mercury chloride poisoning.

\subsection{Other beneficial effects of equine milk and colostrum on human health}

In addition to being seen as an outstanding quality human food, a large number of cosmetics (many with therapeutic properties) are sourced from the milk and colostrum of mares (Claeys et al., 2014). According to Pieszka et al. (2016), equine milk-based cosmetics can soften and make the skin more elastic, facilitating the absorption and retention of water by the skin, and thus contributing to its conditioning.

Zava et al. (2009) evaluated different fractions of mare's milk and colostrum in relation to the efficacy of human fibroblast proliferation in vitro, meaning tissue repair. The results demonstrated clinical efficacy of the emulsion containing colostrum in healing human wounds and skin repair. According to the authors, the biological action of equine colostrum as a tissue repair agent lies in its lipid fraction, although the bioactive molecules may also be proteic with an emphasis on the lactaderines and adipophyllins.

\section{Conclusion}

The use of mare's milk in human consumption is not new, despite it being concentrated in certain regions of the world (especially Central Asia), where it is mainly consumed in the form of kumis. However, scientific revelations about compositional particularities have aroused interest in mare's milk in other countries of the world, especially when it comes to feeding specific groups of people such as children who are allergic to cow milk and convalescent elderly.

Aspects that deserve to be highlighted and which support recommendations for using equine milk as human food are its similarity to human milk, high palatability, the therapeutic properties of kumis (which derive from its richness in probiotics), the balance between casein and whey proteins, the presence of bioactive compounds and the nutritional quality of the lipid fraction. In fact, the results obtained in studies have proven the functionality of this milk as a food and suggest that its incorporation into human diets can bring several beneficial effects to health.

Finally, it is worth noting that the low frequency of consuming mare's milk in the Brazilian diet is notorious, probably due to the scarce dissemination of this exploitation possibility. Considering the vastness of the national equine herd, and also considering the growing tendency of equine milk in the world scenario, it is justified to conduct national studies related to this topic, as these could also contribute to the dissemination of this type of milk as a food.

\section{References}

Abdel-Salam, A. M., Al-Dekheil, A., Babkr, A., Farahna, M., \& Mousa, H. M. (2010). High fiber probiotic fermented mare's milk reduces the toxic effects of mercury in rats. North American Journal of Medical Sciences, 2(12), 569-575. http://dx.doi.org/10.4297/najms.2010.2569. PMid:22558569.

Arruda, P. C. L., Pereira, E. S., Pimentel, P. G., Bomfim, M. A. D., Mizubuti, I. Y., Ribeiro, E. L. A., \& Regadas, J. G. L. Fo. (2012). Perfil de ácidos graxos no Longissimus dorsi de cordeiros Santa Inês alimentados com diferentes níveis energéticos. Semina: Ciências Agrárias, 33(3), 1229-1240. http://dx.doi.org/10.5433/1679-0359.2012v33n3p1229.

Businco, L., Giampietro, P. G., Lucenti, P., Lucaroni, F., Pini, C., Di Felice, G., Iacovacci, P., Curadi, C., \& Orlandi, M. (2000). Allergenicity of mare's milk in children with cow's milk allergy. The Journal of Allergy and Clinical Immunology, 105(5), 1031-1034. http://dx.doi. org/10.1067/mai.2000.106377. PMid:10808187.

Cagno, R. D., Tamborrino, A., Gallo, G., Leone, C., Angelis, M. D., Faccia, M., Amirante, P., \& Gobbetti, M. (2004). Uses of mares' milk in manufacture of fermented milks. International Dairy Journal, 14(9), 767-775. http://dx.doi.org/10.1016/j.idairyj.2004.02.005.

Carroccio, A., Cavataio, F., Montalto, G., D’amico, D., Alabrese, I. G., \& Iacono, G. (2000). Intolerance to hydrolyzed cow's milk protein in infants: clinical characteristics and dietary treatment. Clinical and Experimental Allergy, 30(11), 1597-1603. http://dx.doi. org/10.1046/j.1365-2222.2000.00925.x. PMid:11069569.

Chen, Y., Wang, Z., Chen, X., Liu, Y., Zhang, H., \& Sun, T. (2010). Identification of angio 1-converting enzyme inhibitory peptides from koumiss, a traditional fermented mare's milk. Journal of Dairy Science, 93(3), 884-892. http://dx.doi.org/10.3168/jds.2009-2672. PMid:20172208.

Claeys, W. L., Verraes, C., Cardoen, S., De Block, J., Huyghebaert, A., Raes, K., Dewettinck, K., \& Herman, L. (2014). Consumption of raw or heated milk from different species: an evaluation of the nutritional and potential health benefits. Food Control, 42, 188-201. http://dx.doi.org/10.1016/j.foodcont.2014.01.045.

Costa, V. C. (2013). Avaliação do leite de éguas da raça Crioula: composição e qualidade (Dissertação de mestrado). Universidade Federal do Rio Grande do Sul, Porto Alegre.

Csapó, J., Stefler, J., Martin, T. G., Makray, S., \& Csapó-Kiss, Z. (1995). Composition of mare's colostrum and milk. Fat content, fatty acid composition and vitamin content. International Dairy Journal, 5(4), 393-402. http://dx.doi.org/10.1016/0958-6946(94)00008-D.

Danków, R., Wójtowski, J., Pikul, J., Niżnikowski, R., \& Cais-Sokolińska, D. (2006). Effect of lactation on the hygiene quality and some milk physicochemical traits of the Wielkopolska mares. Archives Animal Breeding, 49, 201-206.

Danova, S., Petrov, K., Pavlov, P., \& Petrova, P. (2005). Isolation and characterization o Lactobacillus strains involved in koumiss 
fermentation. International Journal of Dairy Technology, 58(2), 100105. http://dx.doi.org/10.1111/j.1471-0307.2005.00194.x.

Egito, A. S., Girardet, J. M., Miclo, L., Mollé, D., Humbert, G., \& Gaillard, J. L. (2001). Susceptibility of equine $\mathrm{k}$ - and b - caseins to hydrolysis by chymosin. International Dairy Journal, 11(11-12), 885-893. http:// dx.doi.org/10.1016/S0958-6946(01)00123-6.

El-Agamy, E. I. (2007). The challenge of cow milk protein allergy. Small Ruminant Research, 68(1-2), 64-72. http://dx.doi.org/10.1016/j. smallrumres.2006.09.016.

Faye, B., \& Konuspayeva, G. (2012). The sustainability challenge to the dairy sector - the growing importance of non-cattle milk production worldwide. International Dairy Journal, 24(2), 50-56. http://dx.doi. org/10.1016/j.idairyj.2011.12.011.

Foekel, C., Schubert, R., Kaatz, M., Schmidt, I., Bauer, A., Hipler, U.C., Vogelsang, H., Rabe, K., \& Jahreis, G. (2009). Dietetic effects of oral intervention with mare's milk on the severity scoring of atopic dermatitis, on faecal microbiota and on immunological parameters in patients with atopic dermatitis. International Journal of Food Sciences and Nutrition, 60(Suppl 7), 41-52. http://dx.doi. org/10.1080/09637480802249082. PMid:19462320.

Gibson, R. A., \& Makrides, M. (2000). n-3 polyunsaturated fatty acid requirements of term infants. The American Journal of Clinical Nutrition, 71(1, Suppl), 251-255. http://dx.doi.org/10.1093/ ajcn/71.1.251s. PMid:10617980.

Lara-Villoslada, F., Olivares, M., \& Xaus, J. (2005). The balance between caseins and whey proteins in cow's milk determines its allergenicity. Journal of Dairy Science, 88(5), 1654-1660. http://dx.doi.org/10.3168/ jds.S0022-0302(05)72837-X. PMid:15829656.

Litopoulou-Tzanetaki, E., \& Tzanetakis, N. (2000). Fermented milk. In R. Robinson, C. Batt, and P. Patel (Eds.), Encyclopaedia of food microbiology (pp. 774-805). New York: Academic Press.

Lv, J., \& Wang, L. (2009). Bioactive components in kefir and koumiss. In W. Young (Ed.), Bioactive components in milk and dairy products (pp. 251-260). Ames: Wiley-Blackwell. http://dx.doi. org/10.1002/9780813821504.ch10.

Malacarne, M., Martuzzi, F., Summer, A., \& Mariani, P. (2002). Protein and fat composition of mare's milk: some nutritional remarks with reference to human and cow's milk. International Dairy Journal, 12(11), 869-877. http://dx.doi.org/10.1016/S0958-6946(02)00120-6.

Marconi, E., \& Panfili, G. (1998). Chemical composition and nutritional properties of commercial products of mare milk powder. Journal of Food Composition and Analysis, 11(2), 178-187. http://dx.doi. org/10.1006/jfca.1998.0573.

Markiewicz-Kęszycka, M., Wójtowski, J., Kuczyńska, B., Puppel, K., Czyżak-Runowska, G., Bagnicka, E., Strzałkowska, N., Jóźwik, A., \& Krzyżewski, J. (2013). Chemical composition and whey protein fraction of late lactation mares' milk. International Dairy Journal, 31(2), 62-64. http://dx.doi.org/10.1016/j.idairyj.2013.02.006.

Nikkhah, A. (2012). Equidae milk promises substitutes for cow and human breast milk. Turkish Journal of Veterinary and Animal Sciences, 36(5), 470-475.

Oliveira, M. A. A., \& Osório, M. M. (2005). Consumo de leite de vaca e anemia ferropriva na infância. Jornal de Pediatria, 81(5), 361-367. PMid:16247536.

Ørskov, E. R. (1995). A traveler's view of outer Mongolia. Outlook on Agriculture, 24(2), 127-129. http://dx.doi.org/10.1177/003072709502400211.
Pagan, J. D., \& Hintz, H. F. (1986). Composition of milk from pony mares fed various levels of digestible energy. The Cornell Veterinarian, 76(2), 139-148. PMid:3698598.

Pecka, E., Dobrzański, Z., Zachwieja, A., Szulc, T., \& Czyż, K. (2012). Studies of composition and major protein level in milk and colostrum of mares. Animal Science Journal, 83(2), 162-168. http://dx.doi. org/10.1111/j.1740-0929.2011.00930.x. PMid:22339698.

Pieszka, M., Łuszczyński, J., Zamachowska, M., Augustyn, R., Długosz, B., \& Hędrzak, M. (2016). Is mare milk an appropriate food for people? - a review. Annals of Animal Science, 16(1), 33-51. http:// dx.doi.org/10.1515/aoas-2015-0041.

Pikul, J., \& Wójtowski, J. (2008). Fat and cholesterol content and fatty acid composition of mares' colostrums and milk during five lactation months. Livestock Science, 113(2-3), 285-290. http://dx.doi. org/10.1016/j.livsci.2007.06.005.

Potočnik, K., Gantner, V., Kuterovac, K., \& Cividini, A. (2011). Mare’s milk: composition and protein fraction in comparison with different milk species. Mljekarstvo, 61(2), 107-113.

Rangel, A. H. N., Sales, D. C., Urbano, S. A., Galvão, J. G. B. Jr., Andrade, J. C. No., \& Macêdo, C. S. (2016). Lactose intolerance and cow's milk protein allergy. Food Science and Technology (Campinas), 36(2), 179-187. http://dx.doi.org/10.1590/1678-457X.0019.

Reis, A. D. P., Mesquita, A. J. D., Moreira, C. H. G., Curado, E. A. F., Silva, E. B. D., \& Nicolau, E. S. (2007). Composição do leite de éguas da raça Mangalarga Marchador. Revista do Instituto Adolfo Lutz, 66(2), 130-135.

Salamón, R. V., Salamon, S., Csapó-Kiss, Z., \& Csapó, J. (2009). Composition of mare's colostrum and milk I. Fat content, fatty-acid composition and vitamin contents. Acta Universitaria Sapientiae, 2(1), 119-131.

Salimei, S., \& Fantuz, F. (2012). Equid milk for human consumption. International Dairy Journal, 24(1), 130-142. http://dx.doi.org/10.1016/j. idairyj.2011.11.008.

Santos, E. M., Almeida, F. Q., Vieira, A. A., Pinto, L. F. B., Corassa, A., Pimentel, R. R. M., Silva, V. P., \& Galzerano, L. (2005). Lactação em éguas da raça Mangalarga Marchador: produção e composição do leite e ganho de peso dos potros lactentes. Revista Brasileira de Zootecnia, 34(2), 627-634. http://dx.doi.org/10.1590/S151635982005000200032 .

Schubert, R., Kahle, C., Kauf, E., Hofmann, J., Hubert, I., Gruhn, B., \& Jahreis, G. (2009). Dietetic efficacy of mare's milk for patients with chronic inflammatory bowel diseases - clinical study. Ernährung (Wien), 33(7), 314-321.

Shi, T., Nishiyama, K., Nakamata, K., Aryantini, N. P. D., Mikumo, D., Oda, Y., Yamamoto, Y., Mukai, T., Sujaya, I. N., Urashima, T., \& Fukuda, K. (2012). Isolation of potential probiotic lactobacillus rhamnosus strains from traditional fermented mare milk produced in Sumbawa Island of Indonesia. Bioscience, Biotechnology, and Biochemistry, 76(10), 1897-1903. http://dx.doi.org/10.1271/ bbb.120385. PMid:23047104.

Tafaro, A., Magrone, T., Jirillo, F., Martemucci, G., D’alessandro, A. G., Amati, L., \& Jirillo, E. (2007). Immunological properties of donkey's milk: its potential use in the prevention of atherosclerosis. Current Pharmaceutical Design, 13(36), 3711-3717. http://dx.doi. org/10.2174/138161207783018590. PMid:18220810.

Valverde, R. (2015). Artigo analisa a política do leite na era Vargas. Agência Fiocruz de Notícias. Retrieved from https://agencia.fiocruz. br/artigo-analisa-pol\%C3\%ADtica-do-leite-na-era-vargas 
Vita, D., Passalacqua, G., Di Pasquale, G., Caminiti, L., Crisafulli, G., Rulli, I., \& Pajno, G. B. (2007). Ass's milk in children with atopic dermatitis and cow's milk allergy: crossover comparison with goat milk. Pediatric Allergy and Immunology, 18(7), 594-598. http:// dx.doi.org/10.1111/j.1399-3038.2007.00567.x. PMid:18001430.

Zava, S., Barello, C., Pessione, A., Garoffo, L. P., Fattori, P., Montorfano, G., \& Giuffrida, M. G. (2009). Mare's colostrum globules stimulate fibroblast growth in vitro: a biochemical study. Journal of Medicinal Food, 12(4), 836-845. http://dx.doi.org/10.1089/jmf.2008.0139. PMID: 19735185.

Zhang, W., \& Zhang, H. (2012). Fermentation and koumiss. In Y. H. Hui, E. Ö. Evranuz (Eds.), Handbook of animal-based fermented food and beverage technology (pp. 165). Boca Raton: CRC Press, Tylor \& Francis Group. http://dx.doi.org/10.1201/b12084-12. 